\title{
SHAMBHALA AS A SACRED PLACE: THE CENTRAL POINT OP THE "NOTHING SACRED" SERIES UNIVERSE
}

\author{
Marek Jastrzębski \\ ORCID: 0000-0002-0707-8818 \\ Siedlce University of Natural Sciences and Humanities \\ Faculty of Humanities
}

\begin{abstract}
This article examines the duology of Elizabeth Ann Scarborough, consisting of the novels "Nothing Sacred" and "Last Refuge". The paper aims to present the function of the literary Shambhala in the context of the space-time model of the world presented by the books under study. Based on Mircea Eliade's comparative religion theory, the author puts forward and attempts to prove the hypothesis of a far-reaching similarity between the function of Scarborough's Shambhala in the narrative universe and the meaning of a sacred place in the archaic, religious model of reality.

Key words

Shambhala, science fiction, fantasy, sacred place, Elizabeth Ann Scarborough
\end{abstract}

\section{Introduction*}

"Nothing Sacred" (1991) and "Last Refuge" (1992) - two novels by Elizabeth Ann Scarborough"1, a popular American writer of fantasy and science fiction - are the subject of this paper. The books can be treated as a unified subject of study because

\footnotetext{
* This article has been written on the basis of chapter 3.1 of the author's monograph to be published under the title “The Idea of Sacred Time and Space in Elizabeth Ann Scarborough's Nothing Sacred and Last Refuge". The paper also includes some other short fragments of the monograph.

${ }^{1}$ Scarborough is a respected and experienced writer who deliberately experiments with many styles. She has published about 40 novels (including those in collaboration with Anne McCaffrey). She is also the author of poems, short fictions and essays. In addition, Scarborough worked as an editor, co-editor of anthologies, and a contributor to magazines and newspapers. Some of her novels are aimed mainly at younger readers, as in the case of her humorous, adventure fantasy from the 1980s. Scarborough has also written books on serious social problems, intended mainly for adults. The American author usually sets the storylines of her works in a fantastic alternate universe or in a magical version of the empirical world. Scarborough is probably the best-known for her "The Healer's War" (1988), a fantastic tale based on the author's experiences from the Vietnam War. For this novel in 1989, Scarborough received the Nebula Award from Science Fiction and Fantasy Writers of America (Kumar, 2007; Kies, 1996).
} 
they constitute a duology, and their plot takes place in the same narrative universe invented by the author ${ }^{2}$. As with many non-mimetic texts, in Elizabeth Ann Scarborough's series of novels, the laws of time and space are specifically modified, and their proper understanding seems to be an important factor in the interpretation of this American author's works. In this article, we aim to present the function of the literary Shambhala - a hidden holy land - in the context of the space-time model of the world of the books under study.

Analysing the world presented in the "Nothing Sacred" series in terms of Mircea Eliade's religious studies, one can put forward a hypothesis about a farreaching similarity between the function of Shambhala in this narrative universe and the meaning of a sacred place in the archaic, religious model of reality ${ }^{3}$. According to the famous Romanian scholar, a sacred place was an element binding the spatial and temporal aspect of the structure of the archaic homo religiosus' universe into a whole (Jastrzębski 2002, 25-30). Therefore, a confirmation of the hypothesis will allow Scarborough's Shambhala to be treated as a sacred place par excellence - the central point organising the space-time of the narrative world created by the author. It will also prove that modifications of the rules of time and space of the world presented in the "Nothing Sacred" series can be explained by referring to the analogy with the model of reality typical of archaic religious beliefs. Hence, confirmation of the above hypothesis will also allow us to establish the ontological basis for a possible subsequent analysis of the model of the world presented by Scarborough's “Tibetan duology”.

It should be noted that Scarborough's novels give us relatively little information about Shambhala, or at least too little to deduce the function of this hidden holy land in the cosmological model of space-time on that basis. However, we can take advantage of the fact that Shambhala, as a mystical land hidden somewhere in the mountains of Tibet, is described quite accurately in the myths surrounding it, to which Scarborough refers many times in the "Nothing Sacred" series. Therefore, if the story told by the American author can be regarded as a continuation of the religious myth of Shambhala, then the missing information about this hidden holy land could be supplemented with what is known of its myth.

For the above reasons, we will begin our reflections on Scarborough's Shambhala by introducing the Eastern religious myth of a mysterious supernatural

\footnotetext{
2 "Nothing Sacred" and "Last Refuge" are a series without an official designation. There are two conventions for naming this duology. The first calls it the "Nothing Sacred" series (The Encyclopedia of Science Fiction, 2018; ISDB, n.d.), using the title of the first book. The second convention, instead, refers to the place where the action of the novels is located. According to this tradition, the two following terms are used: the Tibet series (Fantastic Fiction, n.d.) and the "Tibetan books" (Scarborough own webpage, n.d.; FictionDB, n.d.). Below we will use all these terms interchangeably as well as utilising the name "Tibetan duology" that corresponds with the second convention mentioned.

${ }^{3} \mathrm{~A}$ comprehensive description of the Eliadean model of archaic religious worldview can be found in "Patterns in Comparative Religion" (Eliade, 1958).
} 
land, hidden somewhere in the Tibetan Mountains. Then, we will present the theosophical modifications of this myth. Afterwards, we will consider in what sense fantastic novels referring to the Shambhala theme can be regarded as a continuation of its religious myth. In the next research phase, we will present how the Shambhala theme is applied in fantastic literature based on the example of Eliade's "The Secret of Dr. Honigberger" " and Hilton's "Lost Horizon" (1962). All of the above will be consolidated to provide a detailed and coherent picture of Shambhala in the "Nothing Sacred" series. After all the above research steps have been completed, we will consider the appropriateness of treating Shambhala as a sacred place par excellence - the central point of the universe of the "Tibetan duology" by Scarborough.

\section{Shambhala in the myths of Eastern religion}

The term Shambhala derives from Sanskrit and refers to the myth of the land of universal happiness. The mythical story of the kingdom of Shambhala begins with the tale of its King Sucandra, who came to Dhanyakataka in search of wisdom ${ }^{5}$. After the Buddha had passed on to him the teachings of Kalachakra (Sanskr. Circle of Time), Sucandra returned to Shambhala and wrote a sermon that became the basic text of the Tantra of the Wheel of Time (Bernbaum 1980, 233). Each of the King's successors ruled the land for a hundred years, and all the rulers descended from the Buddha's clan and were Bodhisattvas incarnations. Using the wisdom and the writings bequeathed by Sucandra, they taught and initiated their people in the mysteries of the Kalacakra, and under their enlightened authority the kingdom developed until it eventually became one of the most important centres of mystical teachings (Bernaubaum 1980, 234).

According to early Buddhist texts, Shambhala is located north of Bodh Gaya, a Buddhist temple in northern India, but since the kingdom is hidden, it is difficult to determine exactly where. The land is surrounded by mountains in such a way that nobody can see it from the outside, not to mention to gain access there. The journey to Shambhala is possible only through initiation and the use of special spiritual powers. One can say, therefore, that only those whom Shambhala "invites", so to speak, or those brought there by destiny may enter (Bernaubaum 1980, 6).

Rivers and minor mountain ranges divide the Shambhala area into eight regions in the shape of an octagonal lotus flower surrounded by a rosary of snowy

\footnotetext{
4 "The Secret of Dr. Honigberger" was published in English with "Nights at Serampore" in the volume "Two tales of the occult" (Eliade, 1970).

${ }^{5}$ The presentation of the mythical story of Shambhala is based mainly on "The Way to Shambhala" by Bernbaum (1980), who synthesises various versions of the myth, supporting them by oral explanations and comments from Tibetan lamas. His version of transcribing Tibetan and Sanskrit terms is also used in the present considerations. A detailed analysis of the Kalacakra Tantra, including the problem of Shambhala and its history, can be found in the "Studies in the Kalacakra Tantra" by Hammar (2005).
} 
mountains. Each of these eight regions contains twelve principalities. They are ruled by minor kings who owe their loyalty to the King of Shambhala. Their small kingdoms abound in cities with golden roofs on their buildings and parks filled with lush vegetation that never freeze over. Around the centre of the kingdom there is another (symmetric) circle of even higher mountains that shine with the crystalline glow of reflected sunlight. There, at the centre of the kingdom, lies Kalapa, the capital of Shambhala. To the east and west of the city are two beautiful lakes in the shape of a half-moon and a crescent moon, glittering with the precious stones and gems that fill them (Barnbaum 1980, 6-8).

Located in the centre of Kalapa, the King's palace is filled with radiant jewels that make the night almost as bright as day. Various types of crystals embedded in floors and ceilings regulate the temperature of the rooms, emitting cold or heat respectively. When the King sits on his golden throne (located in the centre of the palace), he has a magical jewel at his disposal that fulfils all of his wishes. The Monarch of Shambhala is surrounded by ministers, generals and numerous servants - all ready to carry out his orders. The King also has at his disposal horses, a stone made aircraft, elephants, and other means of transport (Bernbaum 1980, 8). In addition, his palace's warehouses contain countless treasures (including gold and jewels). It can be said that the King of Shambhala possesses enough power and wealth to be the king of the entire world (8).

The residents of the kingdom live in peace, harmony and prosperity. Their harvest is always abundant and their food tasty and nutritious. In Shambhala, all people are healthy and innately beautiful. Every inhabitant has great wealth (gold, jewels), but never has to use it. The laws of Shambhala are just and kind. There is no physical violence or imprisonment there. The inhabitants of this hidden sacred land do not even know the words "war" and "enmity". Many Tibetans consider Shambhala to be the heaven of the gods, while most lamas think of it a "Pure Land", a special kind of paradise designed only for those heading towards Nirvana (Bernbaum 1980,9). The kingdom provides the conditions for rapid progress on the path to spiritual enlightenment. Whoever reaches Shambhala in life or is reborn in this sacred land will never return to a lower state of existence and either reach Nirvana in this life or immediately afterwards (8-10).

It seems like evil has no access to Shambhala at all. The happiness and joy of living there can compete with the happiness of the gods. Hence the name of this land, which simply means "the source of happiness" (Barnbaum 1980, 9). However, despite the qualities of Shambhala that bring it closer to the celestial world of divinity, it is also part of the empirical cosmos and, as such, is connected to the outer world (10). This can be seen especially in the context of Kalacakra's eschatological prophecy, which presents the cosmological function of the hidden kingdom, inextricably linked to its history and destiny. 
According to the prophecy, for three thousand and two hundred years of virtual paradise in the Shambhala kingdom, the conditions in the outside world will gradually deteriorate. People will lose interest in religion and spirituality. Instead, they will turn to egocentrism, war and the desire to dominate others. Dishonesty, greed and unrestrained lust for power will eventually take over the outside world. After crushing the resistance of the remnants of Buddhism, the barbarians who follow the ideology of aggressive materialism will start fighting among themselves for global domination. All sacredness will then disappear from the entire world except for Shambhala. At some point, destruction and chaos will threaten even this sacred kingdom. Then the thirty-second Shambhala King, Rudra Cakrin, will rise from the throne and lead a powerful army of Shambhala warriors against the barbarians. Thus, in the last great battle, the evil king of the barbarians and his army will be destroyed (Barnbaum 1980, 22).

When the battle is over, Shambhala's rule will expand to the whole world, and thus there will be a "golden age" - greater than anything known from the history of humankind. Food will be available to everyone without any effort. There will be no disease or poverty, and all people will receive the gift of longevity. The great saints and wise men of the past will return to life to teach true wisdom, and many people will achieve enlightenment through Kalacakra practice. All living beings will make significant progress in spiritual development because the whole Earth in its "golden age" will become an extension of the kingdom of Shambhala (Barnbaum 1980, 23).

Apart from the Buddhist Shambhala myth presented above, there were similar stories in the East, including the Chinese story of the Hsi Wang Mu Palace, the Indian prophecy of $\mathrm{Kalki}^{6}$ and the myth of Olmolungring known from Bon, the pre-Buddhist religion of Tibet. According to Barnbaum, all these stories can be treated as variations of the same myth, but the Kalacakra version seems to be the most complete ${ }^{7}$. In his opinion, the core of the Shambhala myth is the story of a journey to a hidden sanctuary where the seeker can experience spiritual liberation. Reaching Shambhala results in a spiritual transformation and rebirth of the traveller, but ultimately also of the outside world (Barnbaum 1980,103).

\footnotetext{
${ }^{6}$ Kalki is the final incarnation of the god Vishnu.

${ }^{7}$ Barnbaum argues that the myth of Olmolungring puts relatively little emphasis on the journey and the "apocalyptic war to come" that play such a great role in the Buddhist myth. According to the Bon prophecy, in about twelve thousand years, when religion is extinct in the outside world, the great King and Bon teacher will again come out of Olmolungring. However, unlike Rudra Cakrin, he will not fight in the final battle against the forces of evil; he will simply enlighten humankind with a new and revitalised form of old spiritual teachings (Bernbaum, 1980: 80). The Chinese myth about the Hsi Wang $\mathrm{Mu}$ Palace does not mention the golden age that will come, and the Indian prophecy of Kalki has little to say about Shambhala, its history, and the way to it (103). Because the myth of Shambhala in the version known from Kalachakra is its most complete version, we treat it here as the exemplary model.
} 


\section{The myth of Shambhala in the West}

In the 19th century and the first half of the 20th century, the myth of Shambhala became popular in Western culture. This phenomenon coincides with the renaissance of occultism and the associated obsession with the issue of secret powers that Tibetan lamas were supposed to possess. Western commentators have transformed the myth and adapted it to their intentions and expectations. Some saw in Shambhala, above all, an esoteric source of power that could be used politically and militarily (Berzin n.d.: under "Haushofer, the Thule Society, and Nazi Germany"). Others meanwhile, with the help of the Shambhala myth, wanted to add gravitas to their mystical and occult movements. In the latter trend, for example, the circle associated with the Theosophical Society founded by Helena Blavatsky should be included. In the theosophical interpretation, the myth of Shambhala was combined with stories of other legendary lands known to Europeans, such as Hyperborea, Lemuria, Atlantis and Thule (Berzin n.d.).

Another form of modification of Shambhala's myth was to link it with the story of the underground kingdom of Agharti, which was mainly thanks to the work "Beasts, Men and Gods" by Ferdinand Ossendowski (1922). It is an account of his journey through Outer Mongolia. Ossendowski wrote that he met several lamas there, who told him about Agharti, an underground kingdom located under Mongolia and ruled by the King of the World. According to their reports, when materialism destroys the world, a horrifying war will break out. At that time, the inhabitants of Agharti will appear at the surface of the Earth and help end the violence (Berzin n.d.: under "Ossendowski and Agharti”; Maclellan 1983, 61-72).

\section{The myth of Shambhala in fantastic literature ("The Secret of Dr. Honigberger", and the "Lost Horizon")}

In all the above-mentioned variants of the myth, Shambhala is perceived as a holy land that is difficult to reach but actually exists in the material world ${ }^{8}$. However, another issue is the application of the Shambhala theme in fantastic literature. In this case, the myth is used not to continue the story on a religious plane, but to create an imaginary universe of a novel. This raises the question of whether literary works using the Shambhala theme can be treated as a continuation of its religious myth.

Fantastic novels often use the myth-based discourse about the portrayed reality, which brings this type of literature close to true mythology. Nevertheless, literary references to religious mythologies do not serve the purpose of initiating the adept into the sacred reality. They are used only to stimulate imagination, to make it easier for the reader to immerse in the reality of the alternative world of a novel, to

\footnotetext{
${ }^{8}$ Many times expeditions have been organised to find the kingdom of Shambhala (see Berzin n.d.).
} 
gain the belief that magical phenomena are really true there. This is a function analogous to that which mythology performs in relation to religious beliefs in the real world. We can, therefore, perceive the use of Shambhala's theme in fantastic literature as a continuation of its religious myth, but no longer referring to the real world, but only to the narrative universe of a novel. In other words, one cannot treat a contemporary novel's version of the Shambhala myth in religious categories, but only in literary ones. Nevertheless, we can find interesting variations of this myth in fantastic literature, and when studying the function of Shambhala in the narrative world of a novel, it is worth applying religious studies tools?.

In “The Secret of Dr. Honigberger", Eliade presented Shambhala by referring to his religious studies knowledge of the myth known from Kalacakra, and its occulttheosophical variations. The story focuses on the search for Shambhala by Western occult practitioners. In the narrative, Shambhala and Agharta are treated as one land (Eliade 1970, 90, 111), which is located in the north of India and remains utterly invisible to the uninitiated (110). It can only be accessed by using supernatural powers achieved through advanced yoga practices (111).

In Eliade's story, Shambhala is the "green wonder amid the snow-covered mountains" $(1970,119)$. Its inhabitants have mastered the occult powers of yoga to such an extent that they more often use telepathy than their voices to exchange thoughts. They live in "quaint houses", and their bodies look as if they were "ageless" (119). If it had not been for the magical-mystical effort of the Shambhala people, the entire European continent would have been devastated by the demonic powers that the modern world had released since the Renaissance. Europe would share the fate of Atlantis by dying in the depths of the waters (119).

An interesting take on the Shambhala myth can be found in Hilton's "Lost Horizon". In comparison to the version known from the Kalacakra Tantra, here we are dealing with a whole series of transformations. In Hilton's novel, the term Shambhala does not appear even once. It is a story about Shangri-La, the Tibetan monastery hidden in an idyllic, magical valley, whose inhabitants live apart from the mess of civilisation, wars and struggle for domination. People living in Shangri-La have the gift of longevity. The land is hidden behind a snowy peak called Karakal (invented by Hilton), and only a few chosen ones have access to the path leading to it.

The land is ruled by the High Lama. As he explains to the protagonist of the novel, the purpose of Shangri-La's existence is to preserve the best of Eastern and Western culture for a period when people are possessed by a struggle for power,

\footnotetext{
${ }^{9}$ It is not surprising that writers use Shambhala as a literary theme, a synonym for paradise, or land of fantasy in general. For us, Shambhala is a symbol of the "lost world" - the result of the modern disenchantment of the world. Shambhala is one of the last magical places in which people of the Western secularised culture were inclined to believe to be true. Thus, the myth of Shambhala effectively stimulates the imagination of the reader, facilitates the creation of "faith" in the magic of the narrative world of the novel.
} 
wealth and domination. When wars are over, and world powers destroy each other, the treasures saved in Shangri-La's hidden sanctuary will allow humanity to emerge from the ruins and build a new, better world (Hilton 1962, 191-193). In short, despite many transformations, the basic structure of the Shambhala myth is preserved in Hilton's novel.

\section{4. "Nothing Sacred" series as a literary continuation of the religious myth of Shambhala}

The religious vision of the ancient kingdom of Shambhala and its mythological history, reconstructed above, can be treated as the foundation on which Scarborough creates her own fictional Shambhala. In the Nothing Sacred series, this hidden sacred land is described as completely destroyed due to the ongoing global war. Nevertheless, Scarborough signals links between the Shambala of the "Tibetan duology" and its religious, ancient prototype. The reader discovers glimpses of Shambhala's ancient heritage in the memories of a few survivors of the former hidden kingdom, in extraordinary vivid dreams of the main heroine of the "Nothing Sacred", as well as in "historic finds". The mentioned facts allow us to present the mythological basis of the geography of the "Tibetan duology".

Scarborough creatively uses the religious myth of Shambhala, often rationalising some of its elements. For example, we learn that the golden roofs mentioned in the myth known from the Kalacakra Tantra only looked as if they were made of gold. In the "Tibetan duology", there is only one, and not two sacred lakes in Kalapa. However, despite some changes, the fictional version of ancient Shambhala was described by the American writer following the spirit of the source myth, i.e. as a land filled with beauty, richness of culture, and treasures.

Just as in the case of the mythological description of Shambhala's capital, in its fictional version, the most magnificent building of the entire mystical kingdom is located at its very centre. However, in the "Tibetan duology", this is not the King's palace, but a monastery. In the "Nothing Sacred" series, Kalapa is also not surrounded by a symmetric circle of higher mountains (the source myth), but is situated at the foothill of its guardian mountain, Karakal. These are elements taken from Hilton's "Lost Horizon". Just like the source myth, in Scarborough's novels, Shambhala is isolated from the outside world, protected by powerful magic and accessible only to the initiated. However, it is only in the "Tibetan duology" that this magic is reflected in the physically perceivable "force shield" marking the boundary of this hidden sacred land (Scarborough 1991, 324-325). The "Nothing Sacred" series uses the motif of Shambhala's connection to the outside world through a network of underground tunnels through which its power can be transmitted to some extent (Scarborough 
1992,19). It resembles the equation between Shambhala and Agharti in Ossendowski's book (1922).

It is also worth noting that the American author significantly changes the social system of Shambhala in comparison to its mythical prototype. The King of Shambhala, who was to lead the mystical army to victory over the barbaric materialism of the outside world, does not exist in the world created by Scarborough. The Shambhala of the "Tibetan duology", both in its ancient version and in its reborn form (i.e. as the "new" Shambhala community), does not feature the control of one over the other and is a kind of anarchistic utopia. However, this change is not fundamental in the light of the basic structure of the myth ${ }^{10}$.

In short, Scarborough creates her own Shambhala based on the religious myth known from Kalachakra Tantra, but at the same time makes several modifications. For this purpose, she uses theosophical versions of the myth, Hilton's story of Shangri-La, as well as her own ideas. All the modifications to the source myth introduced in the "Nothing Sacred" series, however, do not violate the character of the religious theme of Shambhala; on the contrary, they are very skilfully inscribed in its mythological history.

\section{In the context of the Shambhala prophecy: Scarborough's "Tibetan duology" as a story of death and the rebirth of the world}

In her duology, Scarborough focuses on the second part of the religious story of the hidden kingdom, the times which in the source myth are described as the triumph of the forces of chaos and destruction, and the coming of Shambhala to help the outside world. The universe described in the "Nothing Sacred" series is influenced by the power of barbaric materialism and, as in the source myth, is heading towards a global war. Compared to the version known from Kalacakra's teachings in the "Tibetan duology", this war is even more severe. The world is almost completely destroyed by nuclear weapons. In a way, the war also destroys Shambhala, killing almost all of its inhabitants.

In the "Nothing Sacred" series, the prophecy known from Kalacakra is fulfilled, although differently than the one described in the source myth. The outside world dies as it sinks into apocalyptic chaos. From this chaos, a new beginning will be born for the world and humanity, unspoiled by the diseases of modern civilisation. People chosen by the spiritual guardian of Shambhala are sheltered within its borders. They rebuild Shambhala and its community, and then the people of the "new" Shambhala

\footnotetext{
${ }^{10}$ The "Nothing Sacred" series contains all the structural elements that Bernbaum treats as the core of the source myth of the hidden, holy land. It tells the story of people chosen by the guardian of Shambhala. After the horrors of war, they find a better life there, and their children (Mike and Chime) set off to help the outside world, which is dying as a result of the war caused by the people's dedication to barbaric materialism.
} 
community will probably set out to populate the world again (Scarborough 1991, 333). In other words, the history of the world depicted in the "Nothing Sacred" series leads to the "new golden age" described by the source Shambhala myth"

\section{Shambhala as a sacred place and the central point of the "Nothing Sacred" series narrative universe}

In the light of the above considerations, we may conclude that the myth of Shambhala, in its source version, in its later modifications (occult and fictional) and finally in the variant of the "Nothing Sacred" series differ in some respects. However, these variations are only secondary, and beyond them, a coherent image of Shambhala emerges. Looking from a religious studies perspective, we can say that the function of Scarborough's literary Shambhala, as well as of its mythological prototype, can be understood in the context of the meaning of the category of sacred place in the archaic, religious model of the universe (postulated by Eliade).

In this paradigm, the world space is imagined as built concentrically around a place considered to be sacred par excellence, i.e. somewhere with a real connection with the supernatural power of the divine sphere of existence (Jastrzębski 2014, 45-46). Therefore, one can say that from the centre of the microcosm of archaic man, the power of the sacred emanates over the entire space inhabited by him. The closer to this centre, the greater the "power of influence" of the sanctity and so space then manifests more features of the sacred sphere of existence. Accordingly, the greater the distance from the centre, the weaker the influence of the sacred, and so the space gradually turns into chaos (Jastrzębski 2002, 26). This description is an excellent reflection of the spatial structure of the Shambhala in Scarborough's "Tibetan duology". The Karakal peak, Kalapa and its lake are located in the centre of the sacred magical land, and it is this place that manifests the most qualities of the sacred sphere of existence in the narrative world. This is why when Shambhala began to deteriorate (along with the growing forces of the chaos in the outside world), Kalapa remained its last inhabited place (Scarborough 1991, 287). Only in Kalapa was the power of Shambhala strong enough to keep plants growing continuously throughout the year.

In Eliade's theory, the border of archaic man's microcosm was the point perceived as the place where the forces of chaos begin to dominate over the sacred (Jastrzębski 2002, 26). Similarly, in the "Nothing Sacred" series, Shambhala's borderline is determined by the reach of its power. The demarcation point between the hidden holy land and the world outside is the "energy shield" protecting this region and its people from the destructive power of the chaos of the external, profane

\footnotetext{
${ }^{11}$ But we should remember that Scarborough only suggests the possibility of the "golden age" somewhere in the future, while the myth known from the Kalacakra Tantra presents it in categories of its historical necessity.
} 
reality (Scarborough 1991, 331). For the people of Shambhala, crossing this border meant the end of the preservation from the destructive power of time (i.e. the loss of the gift of longevity). The "force field" also shielded the inhabitants of Shambhala from the war destroying the outside world. The land remained hidden, and when the entire external reality plunged into a nuclear Armageddon, the "energy shield" protected Shambhala from both the direct effects of nuclear explosions and the deadly consequences of radioactive radiation.

In the Eliadean model of the archaic religious worldview, the sacred place par excellence, as the centre of the world, is perceived as the point which connects all spheres of the cosmic existence and thus constitutes the pillar of the world (Jastrzębski 2002, 28). This concept can also be found in the structure of the narrative universe of the "Tibetan duology". In other words, in the reality portrayed in the "Nothing Sacred" series, the symbolism of Shambhala as the centre of the world also has its vertical counterpart. We can observe this in the "Last Refuge" when Scarborough describes the initiation ritual for children born in Shambhala. During the ceremony, the following statement is uttered:

Know, O best beloved, that you are privileged to be the children of Shambala, which connects heaven and earth and which is located at the precise joining of the two (Scarborough 1992, 5).

Using Eliade's terminology, we would say that in the centre of Shambhala, there is a cosmic pillar, embodied as Karakal, a symbolic cosmic mountain. It connects the earthly sphere of existence with the realm of the sacred. Where these two connect, the power of the dimension of divinity emanates into the realm of mortals. In the world presented in Scarborough's "Tibetan duology", this power manifests itself particularly in Shambhala, ensuring, among other things, the gift of longevity to its inhabitants. As in the model postulated in Eliade's religious studies, so in the fictional world of the "Nothing Sacred" series, to the axis mundi region also belong the surroundings of the cosmic mountain, i.e. Kalapa, its sacred lake located at the base of Karakal, and - in the end - the whole Shambhala land.

\section{Conclusion}

Shambhala in the "Nothing Sacred" series universe functions as the central spot and the cosmic pillar that connects the sphere of celestial divinity with the terrestrial domain of mortals and with the chthonic land of posthumous life (underground regions). From this "middle point" the existence of the cosmos begins, and the power of the sacredness emanates to the whole space of the universe. As in the mythical 
in illo tempore, in the holy place, the power of the sacred descends to the Earth to order chaos, so also in the apocalyptic times announced by the prophecy, in Shambhala, the divine power is supposed to come down to the world, to order chaos, and overcome the evil and materialism of the barbarian civilisation. As demonstrated above, in the "Nothing Sacred" series, this mythological pattern of world history has been preserved. Therefore, considering the matter both in terms of spatial and temporal structure, Scarborough's Shambala is a place of world-forming significance, analogous to the category of a sacred place in the archaic, religious model of reality. Thus, we can state that the hypothesis previously suggested is confirmed. Scarborough's Shambhala is a sacred place par excellence and, as such, is the central point organising the space-time of the entire world presented in the "Tibetan duology".

As a result, the specificity of the spatiotemporal rules of the world depicted in the "Nothing Sacred" series should not be interpreted just as a minor addition of magicality to the natural laws of the empirical reality, but as a reference to a different model of the universe, characteristic of archaic religiosity. Ontologically, space-time is organised here around Shambhala and its history, the sacred place par excellence, the centre of the universe, the point of connection of the sacred and the profane spheres of existence. This connection creates the possibility of miracles in Shambhala phenomena exceeding the space-time limitations of the world of the profane. The abovementioned finding can serve as the metaphysical foundation for any attempt to present a comprehensive model of the world depicted in Scarborough's "Tibetan duology".

\section{References}

Bernbaum, Edwin. 1980. The Way to Shambhala: A Search for the Mythical Kingdom Beyond the Himalayas. Garden City, New York: Anchor Books.

Berzin, Alexander. n.d. "Mistaken Foreign Myths about Shambhala". - Study Buddhism. Berzin Archives e.V. Accessed October 9, 2018. https://studybuddhism.com/en/advanced -studies/history-culture/shambhala/mistaken-foreign-myths-about-shambhala.

Eliade, Mircea. 1958. Patterns in Comparative Religion. Translated by Rosemary Sheed. London and New York: Sheed \& Ward.

Eliade, Mircea. 1970. Two Tales of the Occult. Translated by William Ames Coates. New York: Herder and Herder.

Fantastic Fiction. n.d. "Nothing Sacred”. Accessed August 27, 2018. https://www.fantasticfiction.com/s/elizabeth-ann-scarborough/nothing-sacred.htm.

FictionDB. n.d. "Elizabeth Ann Scarborough Series List”. Accessed August 29, 2018. https://www.fictiondb.com/author/elizabeth-ann-scarborough series-list 23282.htm. 
Hammar, Urban. 2005. Studies in the Kalacakra Tantra: A History of the Kalacakra Tantra in Tibet and a Study of the Concept of Adibuddha, the Fourth Body of the Buddha and the Supreme Unchanging. Stockholm: Stockholms Universitet.

Hilton, James. 1962. Lost Horizon. London: Macmillan.

ISDB [The Internet Speculative Fiction Database]. n.d. "Summary Bibliography: Elizabeth Ann Scarborough”. Accessed August 26, 2018. http://www.isfdb.org/cgi-bin/ea.cgi?1460.

Jastrzębski, Marek. 2002. "Symbolika archaicznego doświadczenia sacrum w ujęciu Mircei Eliadego”. In Antoni Czyż, Jacek Kowzan (eds.), Pogranicza i konteksty literatury, 15-38. Siedlce: Wydawnictwo Akademii Podlaskiej.

Jastrzębski, Marek. 2014. Wczesna filozofia grecka jako archeiczna droga do nieśmiertelności. Próba rekonstrukcji. Białystok: Niepaństwowa Wyższa Szkoła Pedagogiczna w Białymstoku.

Kies, Cosette. 1996. "Scarborough, Elizabeth Ann”. In David Pringle (ed.), St. James Guide to Fantasy Writers, New York: St. James Press.

Kumar, Lisa. [ed.]. 2007. "Scarborough, Elizabeth Ann”. In Something About the Author Facts and Pictures About Authors and Illustrators of Books for Young People. Vol. 171, 153-171. Detroit: Thomson Gale.

Maclellan, Alec. 1983. The Lost World of Agharti: the Mystery of Vril Power. London: Corgi Books.

Ossendowski, Ferdinand. 1922. Beasts, Men and Gods. New York: E.P. Dutton and Company.

Scarborough, Elizabeth Ann. 1988. The Healer's War: A Fantasy Novel of Vietnam. New York: Doubleday.

Scarborough, Elizabeth Ann. 1991. Nothing Sacred. New York: Bantam Spectra Book.

Scarborough, Elizabeth Ann. 1992. Last Refuge. New York: Bantam Spectra Book.

Scarborough, Elizabeth Ann. n.d. "The Tibetan Books". Accessed August 31, 2018. http://scarbor9.wixsite.com /beadtime-stories/tibetan-books.

The Encyclopedia of Science Fiction. 2018. "Scarborough, Elizabeth Ann". Last modified August 31, 2018. http://www.sf-encyclopedia.com/entry/scarborough_elizabeth_ann. 